\title{
Social Democrat Space on Vancouver's Contested Waterfront: Retail, Wholesale, and Department Store Union (CIO) Organizing Amongst Sugar and Grain Workers 1946-1949
}

\section{Chris Madsen}

\begin{abstract}
Le Syndicat des détaillants, grossistes et magasins à rayons, reconnu pour son organisation de campagnes d'adhésion auprès des principaux détaillants en Ontario, a fait son entrée en Colombie-Britannique en établissant une présence précoce et importante auprès de certains travailleurs des quais de Vancouver. Un représentant international au niveau local a recruté des travailleurs pour les syndicats affiliés aux terminaux céréaliers et de raffinerie de sucre, exigé des salaires plus élevés et de meilleures conditions de travail de la part des employeurs, demandé la conciliation dans les négociations et surpassé d'autres syndicats concurrents qui cherchaient à exercer une influence sur les quais. Les travailleurs céréaliers se sont finalement alliés à un autre syndicat, tandis que les travailleurs de sucre de la section locale 517 sont demeurés membres du Syndicat des employés de gros et de détail, dont le siège est à New Westminster.
\end{abstract}

In the latter half of the 1940s, the Retail, Wholesale, and Department Store Union actively organized workers outside existing longshore trades in Vancouver, British Columbia's largest metropolitan city and the biggest commercial port in Western Canada. ${ }^{1}$ Vancouver's large natural harbour accommodated considerable investment in maritime-related infrastructure for loading and unloading ships. Employment on the waterfront was divided by different classes of workers and the unions that represented them with employers. The stories of longshoremen, their work organization, and union traditions are fairly well documented by existing literature

\footnotetext{
1 The author thanks Ray Haynes for sharing memories and photographs of Gerald Emary and the Retail, Wholesale, and Department Store Union.
}

The Northern Mariner/Le marin du nord, XXVII, No. 4 (Oct. 2017), 373-402. 
and historical writing. ${ }^{2}$ Sugar and grain workers, on the other hand, have yet to write union histories because records are lost and memories from retirees are fading. The Canadian side of the Retail, Wholesale, and Department Store Union itself has gone through upheavals and splintered over the decades, which makes any simple history difficult. In Ontario, locals representing thousands of retail and wholesale workers spent a period after 1993 with the United Steelworkers before joining the Canadian Automotive Workers, and now Unifor. The Retail Wholesale Union, based in British Columbia with an office in New Westminster, was created in 1981 when three locals detached from the parent body and sought a provincial charter, and subsequently linked to locals in the Prairie province of Saskatchewan. ${ }^{3}$ Today, locals in the western-based union are affiliated with the coast-wide International Longshore and Warehouse Union (ILWU) and part of its Canadian Area. The Retail Wholesale Union, and its predecessor the Retail, Wholesale, and Department Store Union, deserve to be recognized for longstanding waterfront unionism in Vancouver as much as the ILWU longshore locals. They were there in the beginning and proved just as capable in organizing and leadership.

The Retail, Wholesale, and Department Store Union was an international union organized along industrial lines that formed part of the Congress of Industrial Organizations (CIO) that reached the apex of its influence in the United States and Canada in the years just after the Second World War. Wendy Cuthbertson, in her study of CIO unions in Ontario, ties almost exponential growth in numbers and a search for stability to both economic and cultural factors. ${ }^{4} \mathrm{CIO}$-affiliated unions like the Retail, Wholesale, and Department Store Union took advantage of legal frameworks imposed by governments on industrial labour relations and cultivated political support where possible. Nelson Lichtenstein stresses the close ties between the CIO and the Democratic Party of President Franklin Roosevelt, just as many Canadian CIO unions strongly endorsed the new social democratic movement of the Cooperative Commonwealth Federation (CCF) Party. ${ }^{5}$ Whether representing steelworkers, automotive workers, longshoremen, or workers in other industries, CIO unions drew strength from their rank-and-file memberships and interacted with

\footnotetext{
${ }^{2}$ Peter Cole, “'The Ships Must Sail on Time': Histories of Longshore Workers and Why Their Unions Still Matter," International Labor and Working Class History 83 (2013), 210-225. ILWU Local 500 Pensioners, Man Along the Shore! The Story of the Vancouver Waterfront as told by Longshoremen Themselves, 1860's-1975 (Vancouver, 1975). Chris Madsen, Liam O'Flaherty, and Michelle La, Longshoring on the Fraser: Stories and History of ILWU Local 502 (Vancouver, 2016). Andrew Parnaby, Citizen Docker: Making a New Deal on the Vancouver Waterfront 19191939 (Toronto, 2008).

3 The three locals were 470, 517, and 580. The present Retail, Wholesale, and Department Store Union is American-focussed connected to the United Food and Commercial Workers, separate from the residual former Canadian affiliates. http://www.rwunion.com/

${ }^{4}$ Wendy Cuthbertson, Labour Goes to War: The CIO and the Construction of a New Social Order, 1939-45 (Vancouver, 2012).

${ }_{5}^{5}$ Nelson Lichtenstein, Labor's War at Home: The CIO in World War II (Cambridge, 1982).
} 
one another. The $\mathrm{CIO}$ was a big tent with unions representing a range of political affiliations from left to centre, each exerting degrees of independence in views and actions. The Retail, Wholesale, and Department Store Union, somewhere in the middle, did not come from a communist or radically militant tradition like other CIO unions.

The Canadian Congress of Labour, an umbrella organization for the CIO nationally and regionally, resolved the thorny question of jurisdiction between respective unions and promoted organized labour issues, which occasionally favoured the Retail, Wholesale, and Department Store Union. Benjamin Isitt argues that labour relations in British Columbia represented more a tug-of-war than the post war compromise and accommodation claimed by other historians and industrial relations experts. ${ }^{6}$ Struggles occurred inside and outside the province's unions that featured the rise of new outsiders on the left of the political spectrum. Internally, the contest over Communism eventually split the CIO in British Columbia and undermined its overall effectiveness. ${ }^{7}$ While certain CIO unions in the province weathered inevitable adjustments from elevated wartime industries and cyclical commodity swings, the Retail, Wholesale, and Department Store Union, as a relatively new arrival, was in the ascendancy and redoubled its efforts at organizing. It had to build in order to survive and thrive. The Vancouver waterfront provided good opportunities to convince sugar and grain workers that the union was better able to represent them and their interests than other alternatives.

Outwardly, the Retail, Wholesale, and Department Store Union may seem an unlikely union to have played such as large part in organizing workers on Vancouver's waterfront. Campaign drives to unionize grocery supermarkets and leading chain store retailers in southern Ontario and elsewhere stand out, involving such household names as Loblaws, Dominion, Eaton, Hudson's Bay, and Spencers. ${ }^{8}$ The union never really enjoyed comparable gains on the west coast for retail, and therefore had to be strategic in its organizational activities.

Each union has its own character and origins. Union history remains an interesting sub-field of labour history that has fallen out of fashion amongst Canadian historians focused on social dimensions. Colin Davis, in his comparative study of waterfront workers and their unions in the ports of London and New York post-war, shows that depictions of workplace culture can be combined with sound understanding of the institutional and organizational basis for the functions that

\footnotetext{
${ }^{6}$ Benjamin Isitt, Militant Minority: British Columbia Workers and the Rise of a New Left, 1948-72 (Toronto, 2011), 20. Peter Stuart McInnis, Harnessing Labour Confrontation: Shaping the Postwar Settlement in Canada, 1943-1950 (Toronto, 2002). Laurel Sefton MacDowell, "The Formation of the Canadian Industrial Relations System during World War II," Labour/Le travail 3 (1978), 175-196.

${ }^{7}$ Gordon Hak, The Left in British Columbia: A History of Struggle (Vancouver, 2013), 101-102. Paul Phillips, No Power Greater: A Century of Labour in B.C. (Vancouver, 1967), 142-144.

${ }^{8}$ Lynn Williams, One Day Longer: A Memoir (Toronto, 2011), c. 3.
} 
waterfront unions perform for members, in terms of leadership, interactions with employers, and collective bargaining. ${ }^{9}$ The Retail, Wholesale, and Department Store Union represented an outlier to a dominant historical narrative that asserts the ILWU with its militant and radical agenda was responsible for organizing ports on North America's west coast. The story of how sugar or grain workers were different from longshore brethren is beyond the scope of this article, which simply explains why a smaller, moderate union associated with retail and distribution successfully out-performed a larger rival and proved more attractive to these workers during a specific time period. Generalizations drawn from transposing longshore values and patterns to other industries or extrapolating from one port to another remain problematic, without understanding the differences. ${ }^{10}$ It is clear that maritime historians and labour historians need to recognize groups of workers engaged in waterfront employment and their organizations, distinct from longshore and dock workers.

The receptiveness of sugar and grain workers to the appeals and organizing efforts of the Retail, Wholesale, and Department Store Union on the Vancouver waterfront arose from several external and internal variables. The union and the workers that joined it occupied a moderate middle ground, in a world and labour movement increasingly polarized in the transition years between the end of the Second World War and the early Cold War. Union leaders and the individuals sent as organizers in the field grew the organization by signing up members, creating new locals, and making best use of the industrial legality framework established by government authorities to govern labour relations. Collective agreements followed with principal employers. Sugar and grain workers possessed distinct working cultures based on occupation and the workplace, separate from other workers on the waterfront especially longshore. These groups eschewed Communism, radicalism, and criminality in the prevailing climate that swept across the waterfront and challenged organized labour. The Retail, Wholesale, and Department Store Union's international representative in Vancouver, through his activities and efforts, resonated with the desire for moderation amongst sugar and grain workers and espoused an accommodating approach politically and in relations with employers. Though labour biography may no longer be trendy, Gerald Emary who spearheaded the organizing drives is a labour life worth reclaiming. The success of the Retail, Wholesale, and Department Store Union on Vancouver's waterfront, in outorganizing a far larger and more militant union, relied on personality and a

\footnotetext{
${ }^{9}$ Colin Davis, Waterfront Revolts: New York and London Dockworkers, 1946-61 (Urbana, ILL, 2003).

${ }^{10}$ Peter Turnbull, Julia Morris, and David Sapsford, "Persistent militants and quiescent comrades: intra-industry strike activity on the docks, 1947-89," Sociological Review 44:4 (August 1996), 695. Dmytro Ostapenko, "Forging Regional Connections: The Cold War Internationalism of AsiaPacific Dockworkers," Labour History (Australia) 111 (November 2016), 59-77.
} 


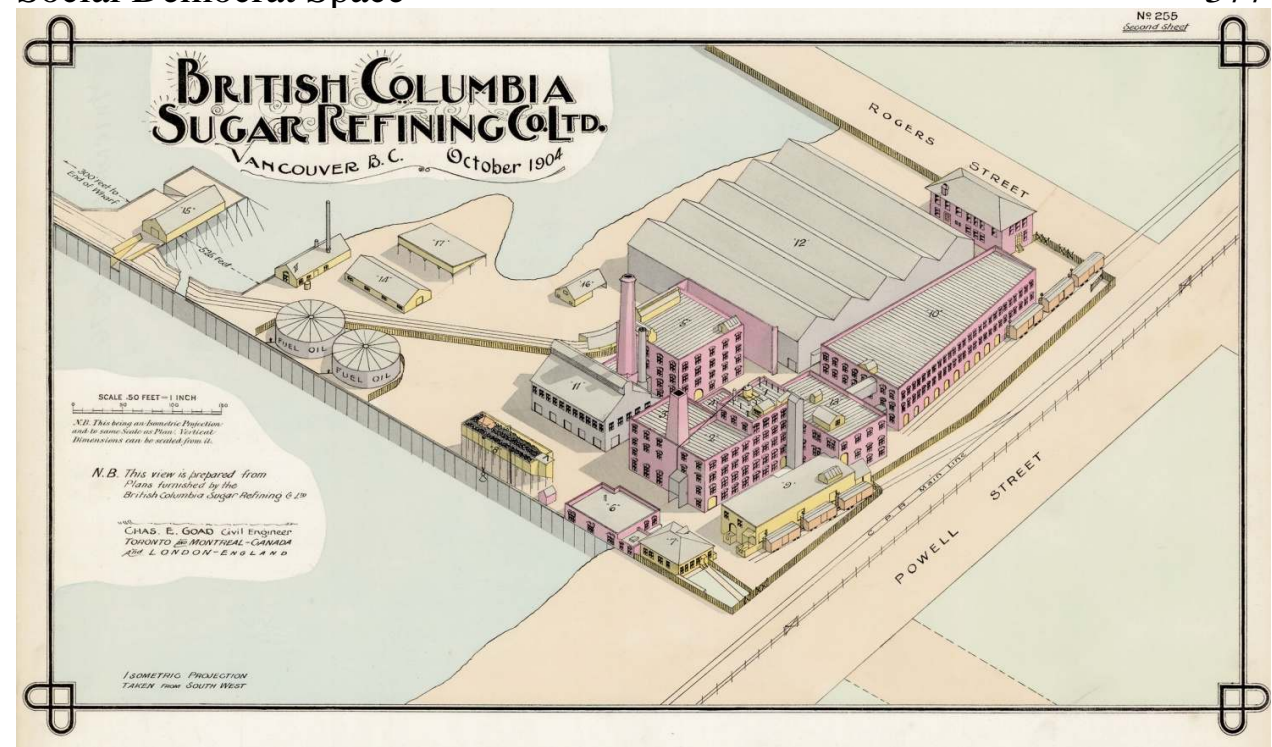

Isometric view from insurance plan of British Columbia Sugar Refining Company's waterfront plant in Vancouver.

Source: R690-154-0-E, Library and Archives Canada

personable approach, finding an amenable clientele amongst select groups of workers.

From earliest days, the Vancouver waterfront was a place of employment and cultural interaction in the daily work process. The British Columbia Sugar Refining Company, among the first major commercial industrial enterprises on the waterfront, erected a plant and wharf in 1891 for the receipt and processing of imported raw sugar cane to serve local and regional markets and later transferred the privately-held lands facing Burrard Inlet to the city in exchange for foreshore rights. ${ }^{11}$ The family business became highly profitable for its millionaire owner, Benjamin 'B.T.' Rogers, and his sons who succeeded him. Raw sugar cane was imported from Fiji, Hawaii, and other Pacific locations, and moved from ship to warehouse buildings or directly into the plant, where it was boiled, pressed, and filtered into syrup to remove impurities, and then evaporated into finished brown or white sugar. Mechanical aids and machines assisted the performance of work functions. The chemical process of refining sugar was little changed over the years from when the plant first came into operation, often with the same equipment. ${ }^{12}$ Handling materials for making sugar involved demanding manual labour from workers of various occupations and skill levels. The British Columbia Sugar

\footnotetext{
${ }^{11}$ Memorandum of Agreement between British Columbia Sugar Refining Company and City of Vancouver, 7 May 1899, RG 42 B-1 vol. 53 file 15040, Library and Archives Canada, Ottawa (LAC).

${ }_{12}$ John Schreiner, The Refiners: A Century of BC Sugar (Vancouver, 1989), 127-128.
} 
Refining Company employed large numbers of women and immigrant workers on the production line. More skilled workers, predominantly male, operated and maintained the machinery and large boilers used in the refining process. Sugar was poured into bags mechanically by machine, checked for quality assurance, and then loaded for distribution to wholesalers and retailers.

Henry Herbert Stevens, Member of Parliament for Vancouver Centre, took an active interest in harbour affairs and successfully obtained funds from the national government for construction of improvements such as piers, wharves, and the first government-run grain elevators. The first stages of planned port development took place in the decades during and following the First World War, under the direction of the Vancouver Harbour Commissioners and after 1936, the National Harbours Board. ${ }^{13}$ Over time, the management model evolved from mixed public-private to predominantly landlord, whereby federal government-owned lands were leased to private terminal operators.

A number of companies and Prairie grain pools completed, bought, or leased grain elevators dating from the late 1920s. The economic downturn of the Great Depression heavily impacted the grain trade and shipping of other commodities, though most companies were large enough to take advantage of lower costs and wages to expand facilities for eventual recovery and pick-up of exports. ${ }^{14}$ Midland Pacific Terminal was located on the north shore of Burrard Inlet, whereas the south shore counted no. 1 and no. 2 of the Alberta Wheat Pool, Pacific Terminal Elevator, United Grain Growers Terminal, and the smallest by far, Columbia Grain Elevator. By 1946, the grain elevators in Vancouver harbour had a total capacity of $18,716,500$ bushels, and a loading rate of 312,000 bushels per hour. ${ }^{15}$ Pacific Terminal Elevator overtook Alberta Wheat Pool No. 1 as the largest grain elevator on the Vancouver waterfront, rated at a design-capacity of more than 7 million bushels. The Vancouver Grain Exchange acted as a mutual association for promotion of shipping grain through the port, and eventually provided the basis for creation of the British Columbia Elevator Operators Association, a collective employer body that dealt with unions representing workers. ${ }^{16}$ Until then, individual private employers determined the wages grain workers received as well as working conditions.

Grain exported through Vancouver area terminals to foreign markets arrived by rail cars from the Prairies, unloaded one-by-by-one onto conveyers. The unprocessed grain was lifted to the top of elevators, where gravity allowed sorting

\footnotetext{
${ }_{13}$ Norman R. Hacking, History of the Port of Vancouver (Vancouver, 1976).

${ }^{14}$ John Everitt and Warren Gill, "The Early Development of Terminal Grain Elevators on Canada's Pacific Coast,” Western Geography 15/16 (2005/2006), 37.

${ }^{15}$ F.W. Riddell to C. Willis George, 20 January 1947, RG 66 E vol. 69 file 46-3 pt. 2, LAC.

${ }^{16}$ Today part of the BC Marine Terminals Operators Association. http://www.bcmarineterminals.com/
} 


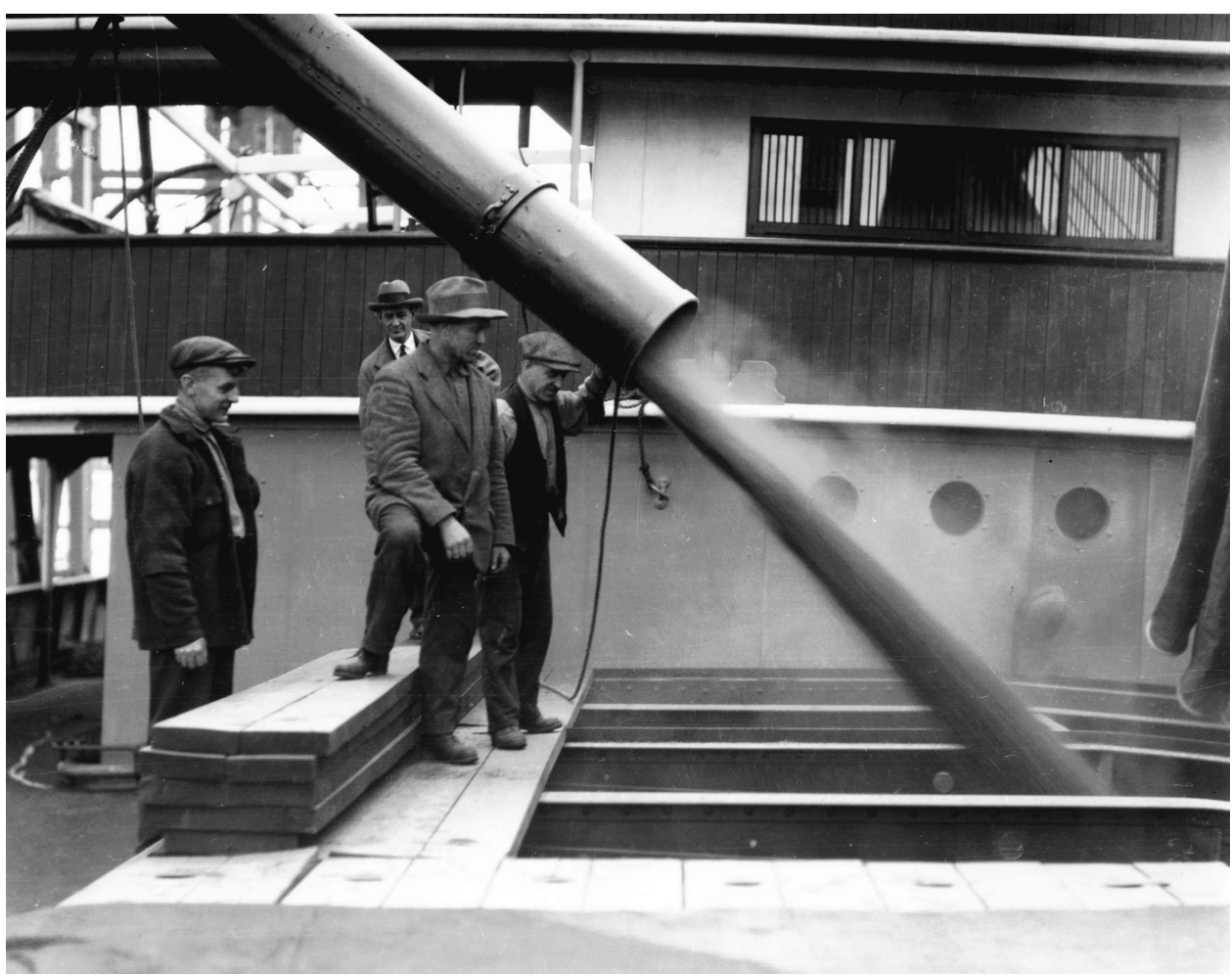

Vancouver grain workers pour grain by spout method into cargo ship's hold. Source: AM1535 CVA 99-1639 Stuart Thomson fonds, City of Vancouver Archives.

and sifting of various types and grades through screens. Different types of grain were stored and seasoned in concrete silos on-site. Many grain workers operated or kept a watchful eye on the machinery used in processing grain. Once finished, the product was ready for loading at nearby wharves. Specialized equipment installed at newer terminals allowed grain to be poured by chutes into the holds of ships. Inside, workers manually shovelled the grain to make sure loads were even. In many cases, the grain was bagged instead and put onto ship by sling load. Grain liners, a related occupation, lined holds with lumber and worked in close proximity with grain workers. Bags were hand-stowed, under the guidance of foremen and stevedores, according to set procedures in order to provide adequate ventilation, prevent shifting during voyage, and avoid mixing and contamination between different types of grains. ${ }^{17}$ Experience and strength were key assets to achieve speed and precision in loading. Working grain between terminal and ship was considered skilled work.

17 R.E. Thomas, Stowage: The Properties and Stowage of Cargoes (Glasgow, 1977), 216-217. 
Sugar and grain workers shared in the same work routine, many serving the machines, in the same workplace, which fostered a feeling of collective identity and a desire for greater representation by their own unions. Group dynamics were subtly different than other waterfront workers. They were more isolated from each other, than longshore workers who typically worked in dispatched gangs. Grain workers tended to work in the same locations, exhibited high levels of specialized skill and experience, and by temperament, were more moderate and independent. They rarely engaged in theft (stealing a whole cargo) or pilferage (stealing part of a cargo) like some longshore workers because the opportunity was not there. Grain workers only loaded different types of grain, and sugar workers only handled the ingredients and products of sugar, specialized commodities. As an occupational health hazard, grain and related dock workers experienced higher levels of respiratory and pulmonary diseases due to prolonged exposure to fine grain dust. ${ }^{18}$ Consequently, they tended to die at ages younger than the average working population. The oral history and recollections that could build a fuller understanding of the workplace culture in a historical context, comparable to Eric Sager's study of Canadian merchant sailors, are largely absent. ${ }^{19}$ Better data on where they lived, what they did outside work hours, and who they congregated with still needs to be collected for any reasonably accurate picture of occupational culture. Sugar and grain workers went to and from the waterfront on a daily basis.

Development of unions for the majority of workers on Vancouver's waterfront was uneven and subject to numerous setbacks at the hands of employers. In 1917, B.T. Rogers steadfastly refused to deal with a union wanting wage increases for sugar workers and hired private detectives and armed guards during a lengthy strike that was crushed. ${ }^{20}$ The management at British Columbia Sugar Refining Company resisted any attempt to form a union at the plant for many years, effectively meaning workers were left unorganized. Grain workers onboard ships, like longshore workers, were subject to the vagaries of the shape-up or ship-side pick of casual labour until the Shipping Federation of British Columbia discontinued the practice in 1931. Earlier accommodating unions representing deep-sea longshoremen fell under more militant and demanding leadership in the run-up to a major strike in 1935 afflicting the Vancouver waterfront, when the entire existing workforce was

\footnotetext{
${ }^{18}$ Helen D. Dimich-Ward, Susan M. Kennedy, Michelle A. Dittrick, Anne DyBuncio, and Moira Chan Yeung, "Evaluation of the respiratory health of dock workers who load grain cargoes in British Columbia," Occupational and Environmental Medicine 52 (1995), 275-277.

${ }^{19}$ Eric W. Sager, Ships and Memories: Merchant Seafarers in Canada's Age of Steam (Vancouver, 1993).

${ }^{20}$ Janet Mary Nicol, "Not Always Sweet: The 1917 Vancouver Sugar Refinery Strike," British Columbia Historical News 35:3 (Summer 2002), 2-5. J.D. McNiven to F.A. Acland, "Strike at Sugar Refinery, Vancouver, B.C. - Called Off,” 25 July 1917, RG 27 reel T-2693 vol. 305 file 21, LAC.
} 
let go and replaced by workers in new company-friendly associations. ${ }^{21}$ Grain workers continued working through that strike and a series of longshore strikes in the United States because they were not yet organized into unions. Even though some blacklisted longshoremen found employment at the grain elevators, managements were careful to keep workers apart from perceived radical ideas attributed to the American movement across the border and screened new hires. Working with grain was very specialized and involved comparatively small numbers of workers. In due course, wartime conditions and government intervention set wages and established compulsory machinery to govern labour relations once workers chose unions.

For the CIO and some of its affiliated unions, waterfront workers appeared ready and willing to be organized. The boilermakers made gains in wartime shipyards, while longshore workers were looking for something different. In July 1943, the ILWU's vice president Rosco Craycraft and secretary-treasurer Louis Goldblatt came to Vancouver from San Francisco espousing the benefits of joining other workers along the Pacific Coast and cooperation with political leaders and governments behind the war effort. ${ }^{22}$ In return for a no-strike pledge, the CIO industrial unions became willing participants in the consultations and decisions of national and regional war labour boards. After several tries, the Vancouver Waterfront Workers Association voted in favour of affiliating with the ILWU and CIO, followed a few months later by the Royal City Waterfront Workers Association in New Westminster.

In September 1943, sugar workers at British Columbia Sugar Refining Company applied for a charter from the Canadian Congress of Labour, as Industrial Union of Sugar Workers Local 1. Nearly half of the 300 employees signed union cards, and numbers steadily grew month to month up to two thirds of the total workforce. $^{23}$

On 23 January 1944, a slate of executive officers was elected from the sugar workers to run the union: Joseph Dockwray, president; Thomas Henderson, vice president, and Osmond Plumbley, secretary-treasurer. A general organizer from the Canadian Congress of Labour's Vancouver office, reported that Philip Rogers, the company's president, was curious about the Canadian arm of the CIO and at least willing to hear from workers wanting a union. In August 1944, the Industrial Union of Sugar Workers Local 1 was certified as the bargaining agent for all employees at British Columbia Sugar Refining Company, including the machine shop and the

\footnotetext{
21 Roy Smith, "Vancouver Longshoremen, Resilient Solidarity, and the 1935 Interruption: Company Unionism 1923-1945," MA thesis, Simon Fraser University, 2013, 64.

22 “CIO Plans Longshore Drive Here: U.S. Officials Move to Organize Port," Vancouver Sun (17 July 1943). R.D. Williams to K.J. Burns, 20 July 1943, RG 66 E vol. 5 file V1-5 pt. 3, LAC.

${ }^{23}$ Monthly remittance reports, MG 28 I103 Canadian Congress of Labour vol. 74 file 12, LAC.
} 
plate shop. ${ }^{24}$ Negotiations began and an application was made to the Regional War Labour Board toward concluding a collective agreement. The union asked management for increases in prevailing wage rates for designated classifications. ${ }^{25}$ A closed union shop, better working conditions, as well as holidays with pay were also desired. Officials from the company and Industrial Union of Sugar Workers Local 1 signed a one-year agreement on 14 February 1945, to bring provisions agreed upon into effect. ${ }^{26}$ Although working through the Regional War Labour Board was slow and inconsistent, the first flirtations with the CIO were generally a positive experience. Jack Phillips remarked that many workers in the union distrusted "reds" though he just wanted "to be another sugar worker with a few bright ideas." 27 The Industrial Union of Sugar Workers Local 1 sought affiliation with another bigger CIO international union from the United States and new to Canada, the Retail, Wholesale, and Department Store Union.

The breakthrough into Canada and the province of British Columbia was a calculated move by the international union and its general executive board. The union was originally organized under the name United Retail and Wholesale Employees of America on 19 May 1937, in the wake of expulsion of CIO industrial unions from the American Federation of Labor, and by 1940 was affiliated with the Canadian Congress of Labour, though no locals existed in Canada at that date. ${ }^{28}$ The international union's power base was in New York City where its office was located and first president, Samuel Wolchok, resided. Wolchok emigrated from Russia as a young man with his parents and family, served in the US Army in France as a machine gunner during the First World War, and became a dominant figure in a New York retail clerks union that John Lewis carried into the CIO and became the basis for the international union. ${ }^{29}$ A tireless organizer, left of centre social democrat, and staunch anti-Communist, he grew the United Retail and Wholesale Employees of America, thereafter renamed Retail, Wholesale, and Department Union, through hard work, attention to detail, and stubborn adherence to his principals. Critics and opponents accused Wolchok of too tight a hold over the union, made worse by policies that deliberately pitted one faction against another

\footnotetext{
${ }_{24}$ Thomas Bradley to Pat Conroy, 24 August 1944, MG 28 I103 CCL vol. 74 file 12, LAC.

25 Revised union classification submission, 1 November 1944, AM 592 BC Sugar 847-A-2 file 1, City of Vancouver Archives, Vancouver (CVA).

${ }^{26}$ Thomas Bradley to Pat Conroy, 17 February 1945, MG 28 I103 CCL vol. 74 file 12, LAC.

27 Jack Phillips to Burt, 8 August 1946, Trade Union Research Bureau box 34 file 34-32, Special Collections University of British Columbia, Vancouver (UBC).

28 Department of Labour of Canada, Thirtieth Annual Report on Labour Organization in Canada (For the Calendar Year 1940) (Ottawa, 1941), 194. The Canadian Retail Employees Union, another separate union at that time, eventually joined the retail and wholesale union.

${ }^{29}$ Peter Kihss, “Samuel Wolchok, Ex-Unionist, 82, Dies," New York Times (18 January 1979).
} 
in an effort to get rid of radical elements. ${ }^{30}$ John Cooney, a long-time secretary and stalwart, stood by the international president. Wolchok and his chosen candidates dominated the general executive board.

Under Wolchok's leadership, the international union pushed its standing upward and outward. President Roosevelt ordered seizure of the store properties and assets of Montgomery Ward, a mail order and department store retail company that had defied investigations and directives from the National War Labor Board to respect an agreement with the retail and wholesale union (the press photographed soldiers physically carrying the company's president, Sewell Avery, out of the Chicago head office). ${ }^{31}$ At the highest point, the Retail, Wholesale, and Department Store Union boasted 450 locals and 180,000 members in the United States. These figures were truly impressive for any union, as Wolchok's span of control and influence grew wider. The general executive board endorsed big plans and goals for a push into Canada. ${ }^{32}$ Expansion north of the border logically fit Wolchok's ambitions to secure the standing of the international union as a leading labour body in North America, if not the biggest, acting for the greatest number of members.

As an organizing entity, the Retail, Wholesale, and Department Store Union launched operations in Canada during September 1945. During a visit to Toronto, Wolchok appointed Thomas MacLachlan as an organizer and salaried employee for the union. He was to be assistant to Norman Twist, the designated Canadian director with an office in the financial district on Bay Street. ${ }^{33}$ Twist, an American, came from St. Louis, Missouri out of a warehouse union that had been absorbed into the retail and wholesale union at the $1938 \mathrm{CIO}$ convention. He had a good background in organizing and occupied several important leadership roles for the Retail, Wholesale, and Department Store Union during the war years. In April 1944, Chicago police snatched him out of a crowd of one thousand workers protesting outside retailer Montgomery Ward, for interfering with strike-breakers going into the plant. ${ }^{34}$ Like Wolchok, Twist was known for his anti-Communist sentiments.

\footnotetext{
${ }^{30}$ Daniel Opler, For All White-Collar Workers: The Possibilities of Radicalism in New York City's Department Store Unions, 1934-1953 (Columbus, 2007), 133-136.

31 Franklin D. Roosevelt: "Executive Order 9508 on the Seizure of Montgomery Ward Co. Properties," 27 December 1944. Online by Gerhard Peters and John T. Woolley, The American Presidency Project. http://www.presidency.ucsb.edu/ws/?pid=16488

${ }^{32}$ General executive board proceedings, 24-29 September 1945, Samuel Wolchok collection 5505 box 1 file 1, Kheel Center for Labor-Management Documentation and Archives, Cornell University Library, Ithaca, New York.

33 Typescript history, Retail, Wholesale, and Department Store Union, Lynn R. Williams collection, RC0172B001 box 1 file 2, McMaster University William Ready Division of Archives and Research Collections, Hamilton. Thomas Ernest Collins, "The Retail, Wholesale, and Department Store Union: The Political Behaviour of a Trade Union in Ontario,” MA thesis, University of Western Ontario, 1974, 23.

34 “1000 Picket Ward Plant in Chicago,” San Jose News (12 April 1944).
} 
The American union brought an antipathy toward Communist elements in the labour movement to Canada.

By the end of 1945, the first Canadian locals were established in Niagara Falls, St. Catherine's, Hamilton, and Toronto. Twist and MacLachlan, however, were not content with just staying in southern Ontario. The next year, they doubled the number of locals in Ontario and signed up members into six locals in Manitoba and three locals in Saskatchewan. The trajectory is shown in Table 1, which highlights the rapid progress in organizing that brought thousands of workers into the union over the span of a few years:

$\begin{array}{rrrr}\text { Year } & \begin{array}{c}\text { Locals in } \\ \text { Canada }\end{array} & \begin{array}{c}\text { Members } \\ \text { Nationally }\end{array} & \begin{array}{c}\text { Locals in } \\ \text { Vancouver }\end{array} \\ \mathbf{1 9 4 5} & 8 & 720 & 0 \\ \mathbf{1 9 4 6} & 29 & 6,000 & 0 \\ \mathbf{1 9 4 7} & 45 & 10,000 & 2 \\ \mathbf{1 9 4 8} & 42 & 5,000 & 3 \\ \mathbf{1 9 4 9} & 36 & 5,500 & 2 \\ \mathbf{1 9 5 0} & 42 & 6,000 & 3\end{array}$

Table 1. Canadian locals and membership in the Retail, Wholesale, and Department Store Union

Source: Canada Department of Labour, Annual Reports Labour Organization in Canada; RG 27 acc. 1988-89/008 box 6 annual labour returns Retail, Wholesale, and Department Store Union, LAC.

The ups and downs in membership numbers reflected pent-up demand for union activity in retail (a non-essential industry in wartime) and the willingness of employers to accept or oppose the Retail, Wholesale, and Department Store Union's organizing attempts, as other unions made inroads by enticing workers away. Addressing delegates at the international union's 1946 convention in Akron, Ohio, Samuel Wolchok acknowledged internal divisions besetting the inflated union and ended on an up-beat note:

We must frankly recognize that the lack of unity within our organization and the failure by important sections of our Union to accept its full responsibilities in the leadership of our Union, created conditions that were not conducive to the growth of a young organization. But despite these setbacks we have made gains. We have won contracts. We have organized 
new locals. We have spread our organization throughout this nation and in parts of Canada. ${ }^{35}$

The best days for the union, Wolchok hinted, were still before them, if they came together. Organizing more Canadian workers into the Retail, Wholesale, and Department Store Union was a key plank in a deliberate growth strategy, to dampen down dissension. Pushing farther west into British Columbia represented the next move by the Retail, Wholesale, and Department Store Union's Canadian director.

Finding a home for the Retail, Wholesale, and Department Store Union in Vancouver culminated several months of behind the scenes lobbying and manoeuvring. Norman Twist sounded out the Canadian Congress of Labour's first vice president, Alex McAuslane, and secretary-treasurer, Pat Conroy, about transferring the Industrial Union of Sugar Workers Local 1 to the retail union's jurisdiction. Conroy appeared a little more agreeable than McAuslane, though both remained non-committal. Overtures to sugar workers in Vancouver by the international union spreading across the continent were hopeful, as the Retail, Wholesale, and Department Store Union told them about organizing at Canadian Dominion Sugar Refining Company in Chatham, Ontario. Writing to Conroy in October 1946, Twist laid out the basic argument for their inclusion:

we have several contracts with large sugar refineries in the [United] States and are, I believe, in a position to service this type of local better than anyone else in the field. My primary reason, however, for wishing the affiliation of this local is to give us some sort of base on which to operate in Vancouver; it being my opinion that a job remains to be done in our field in that area and we wish to open an office and place a man in the field there. $^{36}$

The Retail, Wholesale, and Department Store Union understood the needs of sugar workers better, Twist argued, than other CIO-affiliated Canadian unions. Moreover, he wanted to use the opening to build the international union in British Columbia, particularly into the wholesale and retail fields.

Travelling to Vancouver personally, Twist spoke to the Industrial Union of Sugar Workers Local 1 at a general meeting on 8 November 1946, to outline the benefits of affiliation. Apparently, he was convincing because members chose

\footnotetext{
35 "Proceedings of Fourth Convention, Retail, Wholesale, and Department Store Union C.I.O, May 14th-18th, 1946, Akron, Ohio," A5081 reel 189 file J5 Retail, Wholesale, and Department Store Union, University of Washington Libraries, Seattle (UWL). "Report of Samuel Wolchok, president, United Retail, Wholesale, and Department Store Employees of America, affiliated with the Congress of Industrial Organizations: submitted to the Fourth Convention, convened at Akron, Ohio, May 14th 1946," L 1487, SUNY at Buffalo, Buffalo, New York.

${ }^{36}$ Norman Twist to Pat Conroy, 23 October 1946, MG 28 I103 CCL vol. 38 file 16, LAC.
} 
overwhelmingly, some ninety percent, to return the existing CCL charter and join Twist's international union. Daniel O'Brien, the Canadian Congress of Labour's regional director in Vancouver, confidentially observed: "In discussing this matter with Brother McAuslane on his recent visit here, he did not think these sugar workers rightfully belonged to the Retail, Wholesale Union. A sugar refinery has little to do with wholesale, retail clerks. However, they seem to have voted to go with them and I can only hope that the matter turns out as successfully as their expectations." ${ }^{37}$ The sugar workers were chartered as Retail, Wholesale, and Department Store Local 517 in April 1947. The international union kept its promise to have a representative locally in Vancouver to help the newly affiliated local along and organize.

For most CIO unions, the international representative was an important salaried staff position that was core to organizing and represented the public face of the union in a locale or region. The chosen individual had to be self-motivated, work hard for long hours, act independently with little supervision, honestly handle finances, and always be friendly and welcoming. The role was part salesman, part autonomous executive, and part pragmatic labour promoter. Enthusiasm and working with people were essential to the job description.

The Retail, Wholesale, and Department Store Union acquired a very capable candidate in Gerald 'Gerry' Emary. Only twenty-eight years old when hired, Emary was international representative until his death in 1957 from the complications of surgery. ${ }^{38} \mathrm{He}$ was born in Winnipeg, and moved from the Prairies as a teenager with his family during the Great Depression. His mother's parents were immigrants from Russia, and his father came from Nebraska. Elmer, a brother five years younger, worked as a longshoreman on the Vancouver waterfront. Emary's background was with the steelworkers, another CIO union that had muscled onto the Vancouver industrial scene during and after the war, assisted by the government's mandatory labour relations framework that essentially shut out losing unions. He was actively involved in organizing behind a major strike at American Can Company, a prominent Vancouver area employer. ${ }^{39}$ Politically, Emary supported the CCF, not surprising given the United Steelworkers strong endorsement and work on behalf of that federal and provincial party. In January 1947, he was still listed as secretary of United Steel Workers of America Local 2821 in District $6 .^{40}$ After becoming the retail wholesale union's international representative, Emary continued to work out of the same offices of the steelworkers at the Dominion Bank Building in downtown Vancouver, and subsequently moved to 207 West Hastings Street.

\footnotetext{
${ }^{37}$ Daniel O’Brien to Pat Conroy, 27 February 1947, MG 28 I103 CCL vol. 74 file 13, LAC.

${ }^{38}$ Death certificate 57-09-011574, Gerald Charles Emary, 21 October 1957, British Columbia Archives, Victoria.

${ }^{39}$ McInnis, Harnessing Labour Confrontation, 102.

${ }^{40}$ Margaret Sedgewick to N.S. Dowd, 9 January 1947, MG 28 I103 CCL vol. 45 file 9, LAC.
} 


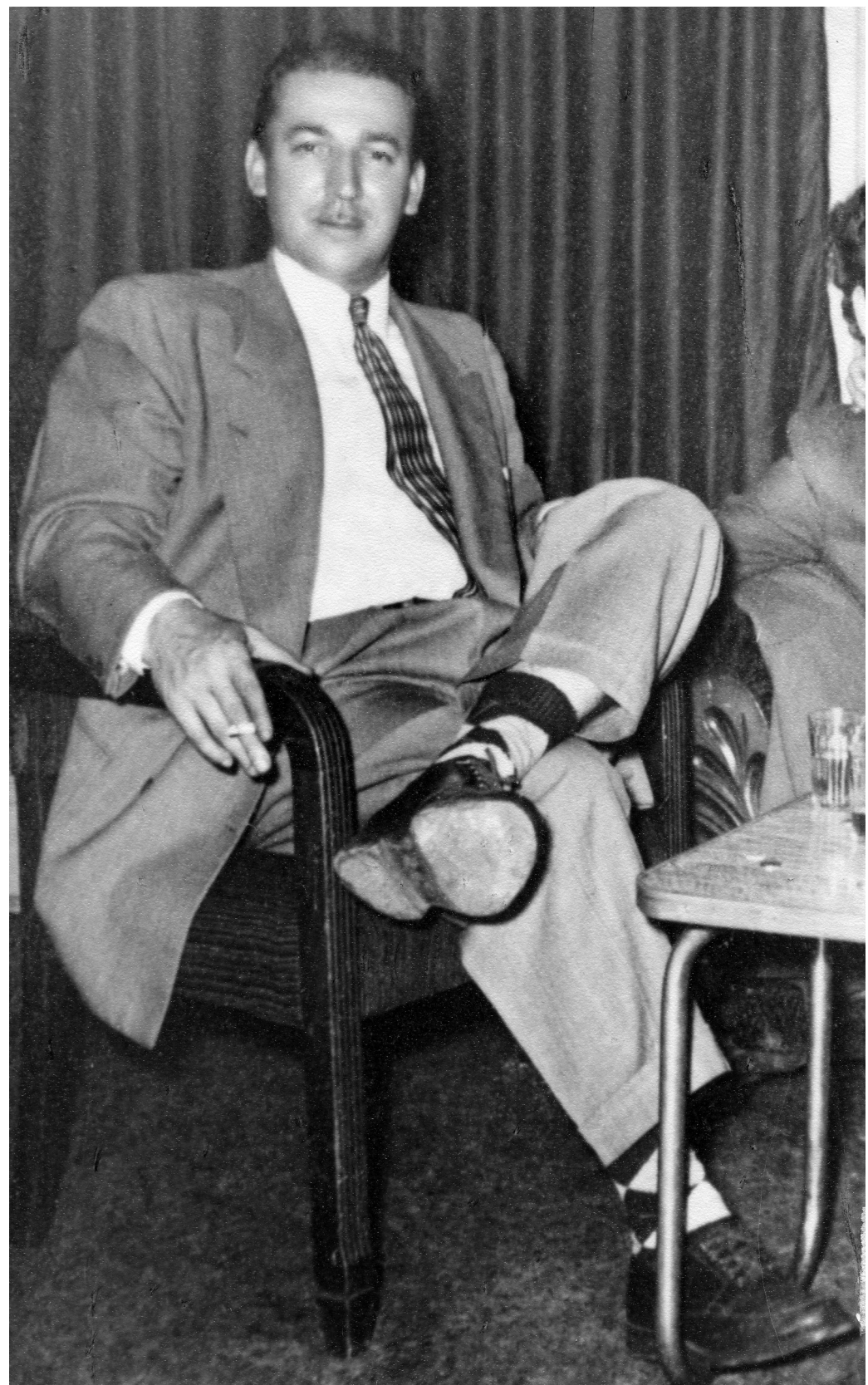

Gerald Emary was the first international representative of the Retail, Wholesale, and Department Store Union in Vancouver. Known as Gerry to his friends and acquaintances, he died at a relatively young age in his late thirties. Source: Ray Haynes 
Emary possessed the innate ability to size up any situation quickly and relate to almost anyone at a personal level. Ray Haynes, a later international representative for the Retail, Wholesale, and Department Store Union who worked with Gerry and considered him a mentor, remembers that Emary usually "preferred to organize out of the nearby beer parlour." ${ }^{41} \mathrm{He}$ frequented spots and places where workers congregated and felt most at ease. For a long time, the streetcar was his chief means of transportation because he neither drove nor owned an automobile. The No. 20 streetcar line ran from downtown servicing residential neighbourhoods and commercial strips along the waterfront as far as Hastings Park in East Vancouver. ${ }^{42}$ Waterfront workers typically lived near where they worked or in places accessible by public transit. Organizing was done by knocking on doors and hopefully getting invited in to chat and learn firsthand the concerns and wishes of workers. Emary, according to Haynes, knew it was too risky for waterfront workers to be seen coming to his office or talking outside workplaces. Organizing waterfront workers, when done well, was discrete.

Sugar workers in Local 517 liked Emary and came to trust him unreservedly. He was elected to the union's bargaining committee at a meeting on 14 March 1947. Vancouver being so distant from the union's centre in Toronto, Norman Twist also put quite a bit of faith in him to do the right thing and act accordingly. Canadian and American officials from the international union visited British Columbia occasionally. Organizing efforts devolved to the person on the spot, to bring sufficient energy, insight, and action to achieve results. Emary fortunately met the test most of the time. The first real challenge was getting Retail, Wholesale, and Department Store Union Local 517 certified for bargaining a better collective agreement, more in line with $\mathrm{CIO}$ aspirations, acceptable to the one existing employer.

Negotiations with British Columbia Sugar Refining provided some movement toward this end. Over the two previous years, Industrial Union of Sugar Workers Local 1 had met with the company regularly on a joint standing committee to discuss terms of employment, grievances, wages, pensions, and other matters. A company-sponsored sick benefit association, dating from 1931, also existed that required contributions from employees and the employer and provided for free medical examinations. ${ }^{43}$ The one year agreement between the union and company, renewed in 1946, provided for continuance past 14 April 1947. When

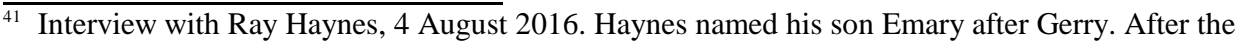
stint with the Retail, Wholesale, and Department Store Union, Haynes was a top official in the BC Federation of Labour.

${ }^{42}$ Rolf Knight, Along the No. 20 Line: Reminiscences of the Vancouver Waterfront (Vancouver, 2011).

${ }^{43}$ The British Columbia Sugar Refinery Employee's Sick Benefit Association Constitution and Bylaws, 1 March 1946.
} 
representatives from Retail, Wholesale, and Department Store Union Local 517 informed the management about the affiliation change the day after, general superintendent Robert Boyd "gave the Union members verbal assurance that the Company has no intentions of taking advantage of the present transitional period and that working conditions will remain unchanged until the new union has an opportunity to negotiate a new contract." 44 The provincial Department of Labour certified Local 517 as the bargaining agent on 22 May 1947, to enter into negotiations with the company.

Emary, as the lead on the bargaining committee and point-man for dealing with Boyd and other company officials, was prominent in talks that started on 3 June 1947, when the union presented a draft agreement. Proposals and counter-proposals went back and forth between the company and the union. What little progress was achieved ended in deadlock over hours of work and wages. On 18 July 1947, Emary applied to provincial minister of labour George Pearson for appointment of a conciliator, Stuart Williscroft, who met with both parties fifteen days after another unsuccessful attempt to reach settlement on their own. With the two sides still far apart, Emary asked for a private meeting with the company's vice president on 7 August 1947, during which he stated "there is considerable dissension among the employees of the Company regarding wages and that he is having some difficulty with a few hotheads who are extremely radical and prepared to go to any lengths to secure substantial wage increases." ${ }^{45}$ The informal approach broke the impasse: Emary obtained a few more cents on hourly rates and double time for six statutory holidays. The company agreed to a written offer from the union setting out the terms, worked into an agreement dated 13 August $1947 .^{46}$

A few on the bargaining committee and in the union still felt Emary should have held out for more. While occasionally betting on race horses at the Hastings track, Emary was unwilling to gamble on a tactic that might end in strike action when all gains so far achieved as well as goodwill might be lost. No walkout by workers had ever been successful against British Columbia Sugar Refining Company. It was a tall order to ask a newly affiliated local to endure a strike that might end in unemployment for union members. The modest advances secured were at least a good start. The international representative thereby averted any vote for an illegal strike and kept sugar workers employed at nominally higher wage rates with better working conditions, protected by contracted agreement. As bargaining on behalf of

\footnotetext{
${ }^{44}$ Union bargaining committee, 15 April 1947, AM 1592 BC Sugar 845-C-3 file 2, CVA.

${ }^{45}$ Memorandum, A.M. Robertson to R. Boyd, "Union,” 7 August 1947, AM 1592 BC Sugar 845C-3 file 2, CVA.

${ }^{46}$ Agreement between the British Columbia Sugar Refining Company, Limited and Industrial Union of Sugar Workers Local No. 517 - C.I.O. affiliated with the Retail, Wholesale, and Department Store Union, C.I.O., Vancouver B.C. 1947-1948, AM 1592 BC Sugar 845-C-3 file 4, CVA.
} 
sugar workers neared an end, Emary turned his attention to organizing grain workers.

Grain workers represented one of the last sizeable groups unorganized into unions on the Vancouver waterfront. The International Longshore and Warehouse Union, led by Harry Bridges in San Francisco, were definitely interested in them and almost took for granted that grain workers would eventually join the American west coast union making inroads in British Columbia. During 1946, the National War Labour Board rejected certification applications by Edward Wennerlow, the local ILWU organizer and international representative, when workers at the two Alberta Wheat Pool and Pacific Terminal elevators opposed International Longshore and Warehouse Union Local 507.47 The ILWU gave insufficient attention to signing up enough grain workers because the overwhelming preoccupation at the time was consolidating gains amongst the chartered locals and bringing in more longshore workers. In a progress report for the year's organizing activities, Wennerlow acknowledged the setbacks and limited progress made amongst workers at Vancouver grain elevators, as well as organizing competition from the Retail, Wholesale, and Department Store Union. ${ }^{48}$ It was also a problem of image and association. Many waterfront workers outside the longshore union considered Harry Bridges a radical and suspected Communist.

Sugar and grain workers had valid reasons to be wary of the ILWU back story. David Witwer and Lee Bernstein stress in separate studies the confluence between officially-inspired red scares and concerns about organized criminal activity in American labour unions during the early Cold War period. ${ }^{49}$ Rhetoric and calls to action targeted specific persons and unions of interest. J. Edgar Hoover's Federal Bureau of Investigation (FBI) investigated Harry Bridges and the ILWU for alleged Communist involvement and labour racketeering. Organized crime infiltrated and manipulated susceptible unions in a myriad of ways and degrees of sophistication, usually with the assistance of well-placed individuals within the union's organizational structure. ${ }^{50}$ Money, power, and monopoly were the chief motivating

\footnotetext{
${ }^{47}$ M.M. Maclean to J. Bennett, 22 August 1946, RG 145 A-1 vol. 38 file 751:364:46, LAC.

48 "Organizational Report from 20th March 1946 to 28th February 1947," ILWU - Organizing -

Canada, box 4 file "Wennerlow, Edward - correspondence 1946-1947," ILWU Anne Rand Library, San Francisco.

${ }^{49}$ David Witwer, "The Racketeer Menace and Antiunionism in the Mid-Twentieth Century US," International Labor and Working-Class History 74 (Fall 2008), 137. Lee Bernstein, The Greatest Menace: Organized Crime in Cold War America (Boston, 2002).

${ }^{50}$ Randolph Boehm, "Organized Crime and Organized Labor," Journal of Social and Political Studies 2:2 (Summer 1977), 92-96. Robert C. Stewart, "Reflections on Labor Racketeering and Interdisciplinary Enforcement," Trends in Organized Crime 9:4 (Summer 2006), 63. In the Canadian context, measuring levels of organized crime in general and specifically amongst labour unions, with any degree of precision or accuracy, is admittedly difficult because most such activity is underground and escapes official attention, despite well-established intelligence gathering and
} 
factors. The bulky FBI file on Harry Bridges ran some 30,000 pages and several thousand more for each of the attorneys in the San Francisco law firm that represented him through deportation hearings, divorce proceedings, and legal trials. ${ }^{51}$ Publically, Bridges was not shy to acknowledge cooperating with Communists and being in sympathy with Communist ideology in defiance of official authority and employer associations when it suited the ILWU's aims and strategy, though he denied ever actually being one. A spurned ex-wife, coached by the FBI, testified that Bridges was indeed a card-carrying Communist, a claim repeated by press reporters without much in the way of substantiated evidence. ${ }^{52}$ Bridges beat several adverse legal rulings and even a five year prison term given for perjury - on each occasion the Supreme Court of the United States overturned lower court decisions and released him from jail. The ILWU steadfastly opposed passage of the restrictive Taft-Hartley Act, which imposed a host of new requirements on trade unions including making labour leaders swear formally to not being Communist. ${ }^{53}$ The American legislation split the labour movement and forced members to choose sides based on loyalty and allegiance. For Hoover's FBI, the only thing worse than a Communist was a crooked Communist.

The greatest perceived threat was eventual joining of the Communist west coast waterfront union with criminal-ridden unions on the east coast. The International Longshoremen's Association (ILA)'s ties with organized crime on New York and other waterfronts were longstanding and established, as were those of the International Brotherhood of Teamsters, led by James "Jimmy" Hoffa, who disappeared under mysterious circumstances after release from prison in 1975 purportedly at the hands of the mob. ${ }^{54}$ Bridges advocated bringing the ILWU and

policing efforts. Rebecca Kong, Chief Policing Services Program, Statistics Canada, presentation to National Coordinating Committee on Organized Crime meeting, "Status of National Policereported Data on Organized Crime," 10-11 December 2015, ATIP A-2016-00031, Public Safety Canada, Ottawa.

${ }^{51}$ Colin Wark and John F. Galliher, "Progressive lawyers under siege: Moral panic during the McCarthy era," Crime, Law, and Social Change 59 (2013), 521. Peter Afrasiabi, Burning Bridges: America's 20-Year Crusade to Deport Labor Leader Harry Bridges (New York, 2016). Ellen Schrecker, "McCarthyism: Political Repression and the Fear of Communism", Social Research 71:4 (Winter 2004), 1057-1058. Athan G. Theoharis, Chasing Spies: How the FBI Failed in Counterintelligence But Promoted the Politics of McCarthyism in the Cold War (Chicago, 2002).

${ }^{52}$ Lionel Youst, "Harry and Agnes Bridges: A Couple at Odds," Pacific Northwest Quarterly 106:2 (Spring 2015), 77. Robert W. Cherny, "The Making of a Labor Radical: Harry Bridges, 1901-1934," Pacific Historical Review 64:3 (1995), 364.

53 ILWU Executive Board meeting, San Francisco, "Statement of Policy on the Taft-Hartley Act," 17 December 1947, Mss 1438 Francis Murnane papers box 4 file 4-15, Oregon Historical Society Research Library, Portland.

${ }_{54}$ James B. Jacobs, Mobsters, Unions, and Feds: The Mafia and the American Labor Movement (New York, 2007). David Witwer, Corruption and Reform in the Teamsters Union (Chicago, 2003). Colin J. Davis, “'Launch Out Into the Deep and Let Down Your Nets': Father John 


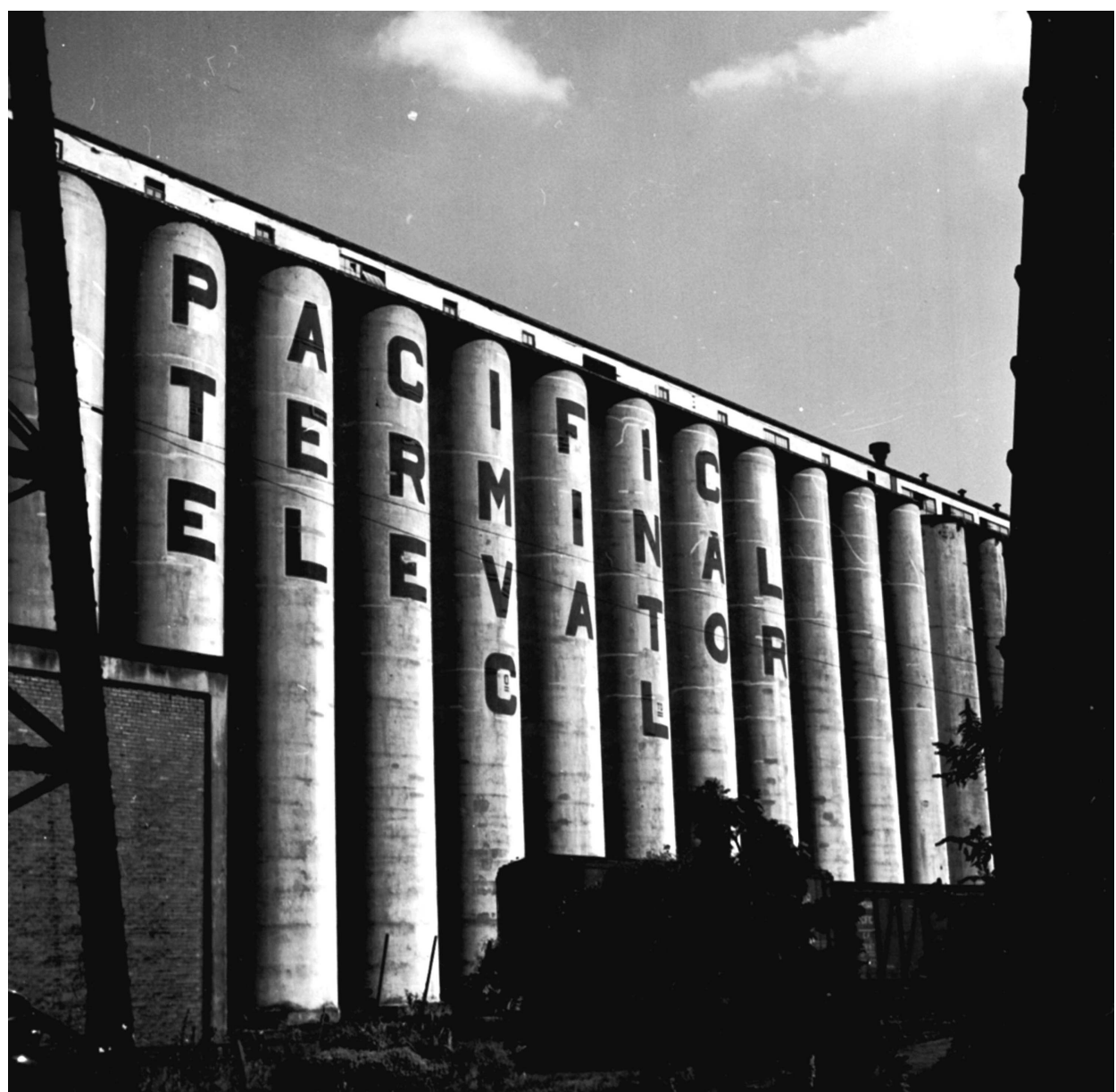

Grain storage silos at Pacific Terminal Elevator

Source: AM 1545-S3 CVA 586-3996 William Brothers collection, City of Vancouver Archives

ILA together, to form a continent-wide waterfront union spanning the United States and Canada. Robert Kennedy, President John F. Kennedy's brother and political sidekick, who officially pursued corrupt labour leaders before and after becoming US attorney general, used the words "unholy alliance" to describe such a prospect. ${ }^{55}$ The ILWU passed resolutions denouncing the federal government's relentless persecution of Hoffa and the teamsters union for criminality. Bridges, like Hoffa,

Corridan, S.J., and New York Longshoremen in the Post-World War II Era," Catholic Historical Review 86:1 (January 2000), 71-73. William Mello, "Docker News: The Struggle for Union Democracy in the Port of New York, 1949-1986," Nature, Society and Thought 20:2 (2007), 137.

${ }_{55}$ Arthur M. Schlesinger, Jr., Robert Kennedy and His Times (Boston, 1978), 160. James Neff, Vendetta: Bobby Kennedy Versus Jimmy Hoffa (New York, 2015). 
occupied the top leadership of his union for decades, by deftly out-manoeuvring opponents and making pacts of convenience. He and the international union handled individual cases of corruption discreetly and tolerated locals in the ports of Los Angeles and Long Beach deregistering black workers en masse in 1946, the socalled "Unemployed 500", in contravention of provisions in the ILWU's own constitution against forms of racial prejudice. ${ }^{56}$ The FBI wiretapped telephones, planted electronic surveillance, and attempted to recruit informants from within ILWU ranks to uncover further evidence of Communist intrigue and criminality. Bruce Hannon, once a close ILWU confidant of Bridges who served in the Royal Canadian Air Force earlier in the war, became disillusioned with the Communist cause and turned against the longshore leader and his tactics. ${ }^{57}$ The carefully constructed narrative surrounding Harry Bridges, verging on hero worship, discounts or ignores that workers inside and outside the ILWU may have held serious reservations about supporting officials tainted with insinuations of Communist activities and labour racketeering.

That same historical narrative celebrates the assumed militant and radical traditions of the ILWU and longshore workers. The Royal Canadian Mounted Police (RCMP), whose E Division in British Columbia shared information and worked closely with FBI field offices in Seattle and San Francisco, categorized the ILWU as a Communist-controlled union, chiefly on the basis of connections with Harry Bridges and Louis Goldblatt. Superintendent Clifford Harvison, the officer commanding in the province, distinguished between those persons espousing Communist ends and responsible labour leaders "constantly trying to rid their organizations of the disruptive influences of Communist infiltration." ${ }^{58}$ The ILWU, until its formal expulsion from the CIO in 1950, fended off accusations that the international union was too dominated by Communist ideology and methods. The Canadian Congress of Labour challenged affiliated unions in British Columbia likewise to reign in Communist agitators, pushed along by the pro-CCF steelworkers. ${ }^{59}$ The CCF, under its federal leader Major James Coldwell, supported

\footnotetext{
${ }_{56}$ Jake Alimahomed-Wilson, Solidarity Forever? Race, Gender, and Unionism in the Ports of Southern California (Lanham, MD, 2016), 62-65.

${ }^{57}$ FBI personal file 100-70808, Statement by Bruce Hannon, 9 February 1954, Collection 5185-1 Ronald Magden collection box 4 file 4-61, Special Collections University of Washington Libraries, Seattle. US Senate, Report of the Subcommittee on Labor and Labor Management Relations of the Committee on Labor and Public Welfare United States Senate Eighty-Second Congress First Session on Communist Domination of Certain Unions (Washington, 1951), 86-96.

58 "Communism in Canada - Lecture to be Given by Supt. C.W. Harvison," Victoria, 29 November 1951, MG 31 E119 Clifford Harvison vol. 1 file 1-6, LAC.

${ }^{59}$ Irving Martin Abella, Nationalism, Communism, and Canadian Labour: The CIO, the Communist party, and the Canadian Congress of Labour 1935-1956 (Toronto, 1973), 116-117. Reg Whitaker and Gary Marcuse, Cold War Canada: The Making of a National Insecurity State, 1945-1957 (Toronto, 1994), 312.
} 
the Western Alliance and North Atlantic Treaty Organisation as guards against Soviet aggression, and shunned any sort of accommodation with the Labor Progressive Party, a respectable version of Tim Buck's older banned Communist Party of Canada. Coldwell worried about "the Communist menace in a democratic country" but opposed "the outlawing of political parties since that is the kind of technique which Communist and Fascist parties have adopted wherever they have come to power." ${ }^{60}$ Whichever side of the divide Canadian ILWU locals actually fell on, longshore workers with the most seniority in the Vancouver area during the post-war period were scabs or strike breakers from the last major waterfront strike in 1935. George Currie, the federal government's local labour mediator, assessed that some sympathy existed "at times for the Communists and Bridges' line", while "no doubt that the longshore unions here have a core of Communists operating under direction and with a definite program." ${ }^{61}$ Other CIO unions on the Vancouver waterfront, such as the boilermakers and shipyard workers, tended toward Communist outlook and leadership. In contrast to multi-part files kept on the ILWU, the Retail, Wholesale, and Department Store Union attracted little attention from RCMP watchers and received no mention of any subversive influence one way or the other. ${ }^{62}$ Grain workers, like sugar workers before them, chose a moderate and "clean" union, over one mired in public spectacle and facing official sanction.

Edward Wennerlow and Gerald Emary, government officials reported, were rivals, politically and across union divides. Grain workers wanted a CIO union, just not the International Longshore and Warehouse Union. Emary's message in the beer halls and talking face-to-face was that another alternative was available in the growing Retail, Wholesale, and Department Store Union. Sugar workers vouched for Emary and his sincerity in fighting for better wages and work conditions. As Emary's personal entreaties attracted more and more grain workers to sign on, organizing at the Alberta Wheat Pool elevators proceeded. Members attending a general meeting on 24 November 1946 decided to elect executive officers, apply for a Retail, Wholesale, and Department Store Union charter for United Grain Elevator Workers Union Local 501, and concurrently seek certification from the National War Labour Board, to cover grain elevators on the Vancouver waterfront.

The sudden coming of United Grain Elevator Workers Union Local 501 irritated other unions claiming the waterfront as their own and consequently invoked strong reactions. In late December 1946, Emary applied formally to Ottawa in respect to bargaining at the Alberta Wheat Pool elevators. As part of the vetting

\footnotetext{
$\overline{{ }_{0}}$ M.J. Coldwell to Nelson Clarke, 9 March 1949, MG 27 III C-12 Major James Coldwell vol. 26 file "Labor Progressive Party" pt. 3, LAC. Reg Whitaker and Steve Hewitt, Canada and the Cold War (Toronto, 2003), 41-43.

${ }^{61}$ G.R. Currie to M.M. Maclean, 24 June 1953, RG 27 B-7 vol. 3482 file 1-101096 pt. 1, LAC.

${ }^{62}$ RG 146 A vol. 2160 file "Retail, Wholesale and Department Store Union Vancouver" pt. 1, ATIP A-2016-00677, LAC.
} 
process, the National War Labour Board canvassed any concerned parties by letter and relied on local labour officials to make investigations. The company accepted Local 501's claim to represent the majority of workers, with only some differences on exempted employees. ILWU Local 507, on the other hand, contested the application from the Retail, Wholesale, and Department Store-affiliated union, which they said did not in fact speak for most grain workers. Edward Wennerlow expressed the nature of those objections in a letter addressed to a National War Labour Board official:

we are still engaged in organizing employees in the Grain Elevator Terminals in Vancouver, which employees we claim are within our jurisdiction both by virtue of membership established before Local 501 appeared on the scene, and by virtue of the fact that the Jurisdictional Committee of the Canadian Congress of Labour has stated that our Local has exclusive jurisdiction over all employees engaged in warehouses, grain elevators and as grain liners. ${ }^{63}$

That so, the majority of grain workers had gone into United Grain Elevator Workers Union Local 501 and were never represented by the ILWU. George Currie verified that the Retail, Wholesale, and Department Store Union had higher numbers of members and questioned the ILWU international representative's genuineness: "In my contacts with Wennerlow, I have found it not only difficult to understand him but have always thought that he had difficulty in following an explanation. He is of Scandinavian origin but, although he has lived in this country some time, he retains quite an accent." ${ }^{64}$ Currie reported that Wennerlow was Communist in sympathies, whereas Emary was firmly CCF, in case Ottawa officials considered political vetting important.

A separate application for the United Grain Growers elevator in late January 1947 encountered a similar situation: Wennerlow contesting, Emary seeking exclusive jurisdiction, and the majority of grain workers actually belonging to United Grain Elevator Workers Union Local 501. After Wennerlow complained, the Canadian Congress of Labour's president wrote Norman Twist: "I am beginning to wonder where all this poaching on the jurisdiction of other organizations is going to end and would respectfully request that you so instruct your representatives in the field as to avoid a continuation of these jurisdictional clashes." ${ }^{65}$ The International Union of Operating Engineers Local 882, a third party, raised further objections to

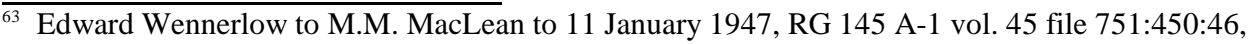
LAC.

${ }^{64}$ George Currie to M.M. MacLean, 14 January 1947, RG 145 A-1 vol. 45 file 751:450:46, LAC.

${ }^{65}$ A.R. Mosher to Norman G. Twist, 11 February 1947, MG 28 I103 CCL vol. 38 file 23, LAC.
} 
the two other unions exercising jurisdiction. None of these entreaties dissuaded Emary from reaching the final goal of keeping grain workers under his union.

On 11 March 1947, the National War Labour Board announced that United Grain Elevator Workers Union Local 501 was certified to enter into negotiations with the companies running the Alberta Wheat Pool and United Grain Growers elevators. Wennerlow and the ILWU came out on the losing end for a second time. The bargaining committee chosen by grain workers included Emary. While beating out the International Longshore and Warehouse Union was salutary in terms of organizing, the Retail, Wholesale, and Department Store Union faced the much harder task of actually having to deliver tangible benefits to workers putting faith in the union, and to do so quickly if possible. The path was not to be easy, as months of contentious bargaining, conciliation, and second thoughts awaited sugar and grain workers.

In order to be effective and legitimate, unions representing workers on the Vancouver waterfront served the interests of rank-and-file members under their respective jurisdictions. Sugar and grain workers along the waterfront now belonged to a union of their own choosing, in locals given a certain degree of self-autonomy to run affairs. The Retail, Wholesale, and Department Store Union constitution required affiliated locals to remit assessments, nominate or elect officers into designated executive positions every two years, hold executive board and regular membership meetings at least once per month, and submit financial reports to the international union at six month intervals. Article XIV stipulated collective bargaining rested with the local's executive board, subject to ratification by members, and article XV provided that strikes "may be called by a local union upon the approval of the International President or his representative, provided that the members or the local Executive Board have voted approval." ${ }^{66}$ Any actions taken were done collectively, in a decided and disciplined way.

To maintain membership, individual union members stayed in good standing by attendance and prompt payment of dues. They came to identify with those around them and the goals of the union. Some went to annual conventions as delegates, while others participated in other ways by serving on shop committees, engaging in extracurricular social and sports activities, and in general striving to be active members to a greater or lesser degree. The union gave workers a sense of solidarity bigger than themselves alone. The international representative and union executive officers interacted with employers on behalf of members.

\footnotetext{
$\overline{66}$ "Constitution of the Retail, Wholesale, and Department Store Union, C.I.O., as adopted May, 1937, and revised at the Fourth Convention of the RWDSU, at Akron, Ohio, May 14-18, 1946 and as amended and revised by referendum of the membership this 16th day of February, 1948," 54-55, A5081 reel 189 file J5 1948, UWL.
} 


$\begin{array}{llc} & \text { Grain } & \text { Raw Sugar } \\ \mathbf{1 9 4 6} & 1,720,804 & 39,534 \\ \mathbf{1 9 4 7} & 1,336,804 & 82,793 \\ \mathbf{1 9 4 8} & 1,121,772 & 92,793 \\ \mathbf{1 9 4 9} & 2,113,348 & 82,108 \\ \mathbf{1 9 5 0} & 1,499,545^{*} & 104,480\end{array}$

Table 2. Tonnage of grain exported and sugar imported as commodities through the port of Vancouver.

Source: RG 27 acc. 1993-94/065 box 48 file 528-17-14/21 pt. 1, Library and Archives Canada.

* A major railway strike blocked and halted the shipment of grain from the Prairies to the west coast, which reduced monthly and annual numbers for 1950 .

Negotiations between companies operating on the Vancouver waterfront and the two Retail, Wholesale, and Department Store locals for agreements followed a familiar pattern during the next two years. Table 2 indicates that waterfront work related to grain and sugar shipped through Vancouver steady increased due to healthy commodity numbers. Gerald Emary was front and centre in bargaining between unionized workers and waterfront employers. Close to expiry, the union put forward a proposal for advancements, company officials equivocated by citing market conditions, a deadlock was reached, the international representative applied for conciliation, and after some back and forth, the respective sides reached a modest settlement, either with or without the conciliator's help. An agreement signed with British Columbia Sugar Refining Company on 4 November 1948, to replace the one from August the year before, came out of talks commenced in August when Emary's repeated use of the phrase "first things first" exasperated the employer and led to his written request for appointment of a conciliator by the provincial minister of labour on 22 October $1948 .{ }^{67}$ Small details were still being worked out last-minute up to the meeting for final signatures. Negotiations for the grain workers in Local 501 started in August, and Emary requested the federal minister of labour appoint a conciliator on 1 October. ${ }^{68}$ An agreement was not reached until late November 1948. The negotiations for the two locals ran in parallel, and Emary devoted much of his time during these months to collective bargaining, which could only come at the expense of further organizing and routine administration. Meetings with employers often went into the long hours and involved some testy exchanges and going over the minutiae of wording in draft

\footnotetext{
${ }^{67}$ Agreement between the British Columbia Sugar Refining Company, Limited and Industrial Union of Sugar Workers Local No. 517 - C.I.O. affiliated with the Retail, Wholesale, and Department Store Union, C.I.O., Vancouver B.C. 1948-1949, AM 1592 BC Sugar 845-C-3 file 3, CVA.

${ }^{68}$ G.C. Emary to M.M. Maclean, 1 October 1948, RG 27 F-2 vol. 1804 file 760-5-48, LAC.
} 


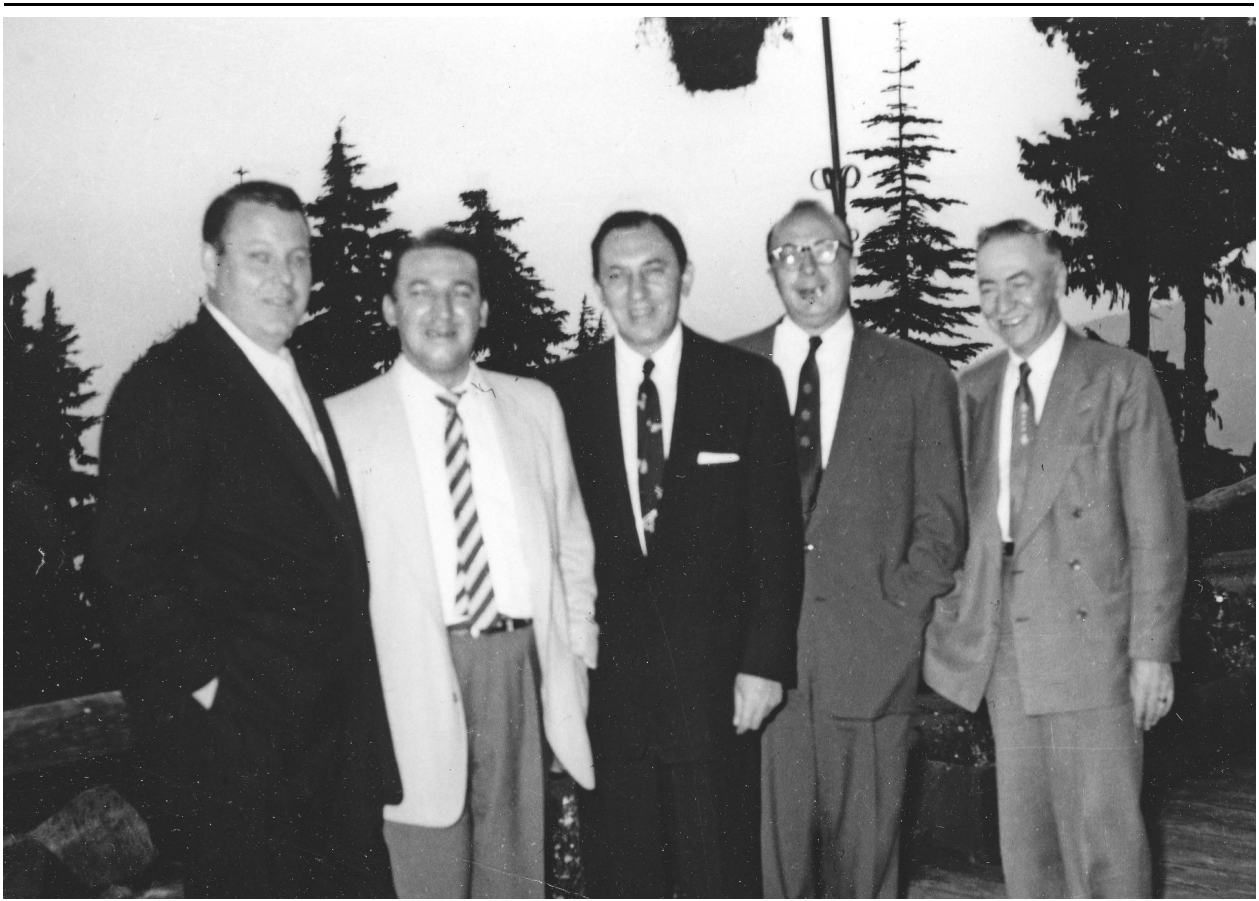

Gerald Emary (second from left), flanked by international officers Alvin Heaps and Max Greenberg in Vancouver's Stanley Park. Heaps, a war veteran, was a long serving secretary treasurer before becoming international president of the Retail, Wholesale, and Department Store Union in 1976. In December 1981, he was severely injured opening a mail bomb disguised as a Christmas package delivered to the international office. Heaps survived the blast and lived another four years.

Source: Ray Haynes (photograph); "Alvin Heaps, 67, Dies: Retail Union President," New York Times (9 September 1986).

agreements.

As a people person, Emary most likely disliked that aspect of the job, no matter how necessary, and probably explains his differences with some of the local executive officers serving as fellow bargaining representatives, that lingered long afterwards. The veto held by Emary on strikes in particular rankled some union members. They disliked his tendency to water-down provisions and accept compromises on wage demands in return for settlements. The strategy made sense to an international union trying to have a national presence in Canada and a reputation for delivering signed agreements on behalf of members, though the wider context was rarely apparent to waterfront workers in the Vancouver locals. Further organizing into retail and wholesale naturally was the end goal of the union and its top officials, and took higher priority. Emary was ready to pivot into a major campaign to sign up workers locally at Army and Navy and Woodward's 
department stores, once the sugar and grain workers were looked after for another year. ${ }^{69}$ Higher up, the Retail, Wholesale, and Department Store Union confronted its own troubles that loomed large for coordinated organizing drives in British Columbia.

The Retail, Wholesale, and Department Store Union, a big union that acted like a small one, was near implosion. The union's growth strategy was wildly successful in many respects, though the critics were never silenced and large numbers of new members brought in from all sorts of fields beyond retail and wholesale possessed variable allegiances. Thousands left for other unions, and among those who remained, calls for change became louder. Samuel Wolchok's days as international president were nearing an end, whether he knew it or not. He had hung on for too long and made too many enemies. Wolchok fended off allegations of financial irregularities in union business and organizing during a trial conducted by the union. Norman Twist, writing to Conroy, worried about the factional in-fighting besetting the US side of the union: "We have tried here in Canada to keep as much of this out of our locals as possible because I do not believe that this sort of thing is conducive to the building of a union. However, some people are completely irresponsible in this regard and have continued to send attacks against the president and the administration, as you put it - across the entire continent." ${ }^{, 70}$ The president himself was responsible for much of the internal dissension, since he fostered it to keep a hold on power. Weary after another long fight with a competing CIO union over organizing American department store workers, Wolchok took an extended leave of absence in December 1948, from which he never returned. The leadership transition had been painful and difficult.

Amidst the turmoil and intrigue, the union progressively shrank and money became tighter. The Canadian office starved the locals of funds to cover costly and prolonged public organizing drives in Toronto at Eaton department stores. ${ }^{71}$ Emary, like other international representatives, reluctantly took cuts in salary and allowances. In February 1949, Norman Twist abruptly quit and departed the union, which left Thomas MacLachlan in charge. ${ }^{72}$ The Retail, Wholesale, and Department Store Union retrenched and refocused geographically - British Columbia took second stage to Central Canada. Irving Simon, the new international president in 1949, was a Wolchok confidant and continued some of the same policies, though the besieged and increasingly emaciated union was under enormous pressure. Alvin

\footnotetext{
${ }^{69}$ Trade Union Research Bureau, "Retail, Wholesale, and Department Store Union Local 535 Submission to Conciliation Board," 15 June 1949, Trade Union Research Bureau, box 34 file 3429, UBC.

${ }^{70}$ Norman Twist to Pat Conroy, 26 November 1947, MG 28 I103 CCL vol. 39 file 2, LAC.

${ }^{71}$ Eileen Sufrin, The Eaton Drive: The Campaign to Organize Canada's Largest Department Store, 1948 to 1952, 2nd edition (Toronto, 1983).

72 T.B. MacLachlan to Norman Dowd, 22 February 1949, MG 28 I103 CCL vol. 38 file 19, LAC.
} 
Heaps, the secretary treasurer since 1948, warned that the Retail, Wholesale, and Department Store Union gave a prime target for poaching from other industrial unions claiming jurisdiction. In this context, grain workers on the Vancouver waterfront decided to leave the retail and wholesale union.

The choice of Vancouver grain elevator workers to switch affiliation to the International Union of United Brewery, Flour, Cereal, Soft Drink, and Distillery Workers of America, away from the Retail, Wholesale, and Department Store Union, was really just a matter of timing. In a deal struck with the Canadian Congress of Labour, it was agreed to transfer locals covering certain breweries in Ontario and other provinces to the newer union setting up operations in Canada and in need of financial resources and members. The Retail, Wholesale, and Department Store Union, by slimming down, could then devote more resources to organizing core groups in the retail and wholesale trades. Emary, being on the front lines of organizing, appreciated that redefining focus and effort was long overdue. Grain workers instantly became orphans.

Even more astounding, the grain workers actually wanted to go while being pushed out the door. Members in United Grain Elevator Workers Union Local 501 attending a meeting on 23 April 1949 voted to accept a motion from John Leach, the local's president, to change affiliation. Leach had sat on the bargaining committee with Emary during the last round of collective bargaining. The two men disagreed on many things. The International Union of United Brewery, Flour, Cereal, Soft Drink, and Distillery Workers of America issued a charter for United Grain Elevator Workers Union Local 333 on 2 May 1949.

Neither Emary nor ILWU international representative John Berry offered objections to the change in affiliation, which was done by mutual consent of all concerned. Berry, focused on longshore affairs, had no interest in grain workers. Edward Sims, representing the International Union of United Brewery, Flour, Cereal, Soft Drink, and Distillery Workers of America, made application to the Canadian Labour Relations Board for certification of Local 333 at the Alberta Wheat Pool, which had sixty-two unionized employees. ${ }^{73}$ Once approved on 16 August 1949, this grain elevator was the first in Canada coming under the jurisdiction of the International Union of United Brewery, Flour, Cereal, Soft Drink, and Distillery Workers of America. Sims, according to an RCMP investigator's assessment on a report from a confidential informant close to the union, was "regarded locally in trade union circles as being a militant trade unionist and, a person who will not co-operate with the Communist Party in any way." ${ }^{.74} \mathrm{He}$ was

\footnotetext{
${ }_{73}$ E.C. Sims to M.M. Maclean, 31 May 1949, RG 145 B-1 vol. 92 file 766-66-49, LAC.

${ }^{74}$ Staff Sergeant A.R. Campbell, E Division Security Intelligence Branch Vancouver Detachment, "Local 333, International Union of United Brewery, Flour, Cereal, Soft Drink and Distillery Workers of America (A.F.L-C.I.O./C.L.C)," 9 November 1960, RG 146 A vol. 2161 file "International Union of United Brewery, Flour, Cereal, Soft Drink and Distillery Workers of
} 
proof that organizers could aggressively push legitimate labour union interests and goals, without being branded or considered committed Communists.

United Grain Elevator Workers Union Local 333, under Leach and other executive officers, negotiated agreements with Vancouver waterfront employers operating grain elevators, the name changed to Grain Workers Union Local 333 after December 1952. Emary continued to bargain on behalf of sugar workers, represented by Retail, Wholesale, and Department Store Union Local 517, whom remained affiliated after 1949. Unlike grain workers, they found a place under the existing union on the Vancouver waterfront.

The Retail, Wholesale, and Department Store Union became a fixture on the Vancouver waterfront during the years 1946 to 1949 , largely on the basis of aggressive organizing amongst sugar and grain workers. As part of ambitions plans to grow the international union and establish a presence across Canada, the upstart union straddled jurisdictional lines and offered a moderate and safe alternative to other competing unions linked publically to possible Communism and labour racketeering. Differentiated workplace cultures and a sense of independent organization dissuaded them from joining longshore workers in the ILWU. Sugar and grain workers instead turned to the Retail, Wholesale, and Department Store Union, encouraged by the entreaties and organizing efforts of Gerald Emary. Emary and the Retail, Wholesale, and Department Store Union beat out the much larger ILWU by taking grain workers into their own local, and negotiated beneficial collective agreements with employers through negotiation and conciliation, without resort to strike action. The union and its local international representative occupied a middle ground in a polarized labour movement, with pressures coming from below as well as from above. It is a corrective to the prevailing view amongst some labour and maritime historians that Communism was dominant within maritime labour in British Columbia during this time. The Retail, Wholesale, and Department Store Union, as a waterfront union, was marked for its moderation and lack of allegiance to any form of Communism. Good organizing advanced legitimate labour union interests, in ways that benefited the concerns and desires of represented workers. Sugar workers stayed in the fold, while grain workers eventually struck out on their own.

It has only been recently that Grain Workers Union Local 333 returned to affiliation with the International Longshore and Warehouse Union, after a short interlude in 1975 when the teamsters absorbed the International Union of United Brewery, Flour, Cereal, Soft Drink and Distillery Workers of America. Retail, Wholesale, and Department Store Union Local 517, representing sugar workers, was one of the founding locals of the Retail Wholesale Union, the current union

America British Columbia,” ATIP A-2016-00673, LAC. Ray Haynes narrowly beat Sims in a contest for secretary-treasurer of the BC Federation of Labour. Interview with Ray Haynes, 4 August 2016. 
based in British Columbia and New Westminster that is affiliated with the ILWU Canada. The origins of this union go back to the fights and concessions over organizing sugar and grain workers in the post-war years. The accomplishments of international representative Gerald Emary, and those who came after him who contributed to building a strong union, remind a broader membership that union history, and in fact the history of their unions, has some value, even today. The Retail, Wholesale, and Department Store Union arrived on the Vancouver waterfront in the early days, alongside the union locals representing longshore workers. That is an important point to remember, as today's sugar and grain workers construct their own historical narrative and learn from the past. 